\title{
Fisheries management and governance in Bangladesh
}

\begin{abstract}
Bangladesh is considered as one of the most suitable riverine country endowed with the rich inland and marine fisheries resources with enormous aquaculture potential. The suitable geographical location of Bangladesh along with its huge number of aquatic species offer excellent opportunities for the effective utilization and management of fisheries resources. Fisheries sector in Bangladesh represents as one of the most productive and dynamic sectors in the country. The country's fisheries sector plays a significant role in food security, employment, and foreign exchange earnings in the economy. The sector contributes $3.65 \%$ to the national GDP and $23.81 \%$ to the total agricultural GDP. Fish and fishery products are the country's second largest export commodity contributing 1.97 percent of its exchange earnings in 2015-2016. From the year 2000 to 2016, aquaculture production increased from 712,640 to $2,060,408 \mathrm{mt}$, which was much higher than wild capture production of 1.023 million $\mathrm{mt}$ in 2016 . There has also been a recent increase in the value of fishery exports, with more than US $\$ 34.08$ billion in 2010 rising to more than US $\$ 46.60$ billion in 2015. However, total fisheries production is much below the production targets, despite large gains have been observed in the aquaculture sector. Nevertheless, the fisheries sector in the 21st century is facing the challenges of food security for the increasing population, habitat degradation, urbanization, and industrial development. Development of responsible fisheries management and optimal use of water bodies can address those challenges. Since fishery is a productive growth sector in Bangladesh, it has high potential to contribute in the socioeconomic development of the country. In this paper, we also make an attempt to examine the current legal status of Bangladesh fisheries and constraints in the implementation of fisheries laws. It is identified that twelve fisheries regulations are executed for the regulation and management of the fisheries resources in Bangladesh. Among these laws, a few are historically important for the regulating and managing of fisheries. These laws are implemented with some amendments towards the development of legal mechanisms for fisheries development of Bangladesh. The implementations of these laws often met limited success due to a number of shortcomings in the legislations. The constraints in the implementation are the lack of clear policy guidelines and strategy, inadequacy of existing regulatory framework, non-enforcement of legislation and jurisdictional conflicts, the absence of regular law review and updating mechanism and formulation of by-laws, rules, orders etc. However, in recent years, Bangladesh Government has taken some initiatives towards the conservation and management of fish stocks (e.g., hilsa fishery), both to optimize total production and ensure fisher's livelihoods. Furthermore, a comprehensive legal framework is required for sustainable management of fisheries resources in Bangladesh.
\end{abstract}

Keywords: fisheries resources, management strategies, legal framework governance system, fisher's livelihoods, Bangladesh
Volume 3 Issue 6 - 2018

\author{
M Aminur Rahman,' Sang-Go Lee,' Md \\ Habibur Rahman Molla,' OE Asare,' FO \\ Megwalu,' Bushra Jahan, ${ }^{2}$ M Muzzamil \\ Shaikh' \\ 'World Fisheries University Pilot Programme, Pukyong National \\ University (PKNU), Korea \\ ${ }^{2}$ Biotechnology and Genetic Engineering Discipline, Khulna \\ University, Bangladesh
}

\author{
Correspondence: M Aminur Rahman, World Fisheries \\ University Pilot Programme, Pukyong National University \\ (PKNU), 45 Yongso-ro, Nam-gu, Busan 485I3, Korea, Tel + 8251 \\ 629 6675, Fax +8251 629667 , \\ Email amenur1963@gmail.com, amenur2017@pknu.ac.kr
}

Received: November 23, 2018 | Published: December II,

2018

\section{Introduction}

Bangladesh is fortunate enough for being a riverine country having rich inland and capture fisheries with huge aquaculture potential. The suitable geographical location of Bangladesh in the region along with a large number of aquatic species offer excellent opportunities to support fisheries potential and resource management. ${ }^{1}$ The country's fisheries sector has been playing a vital role in alleviating protein shortage, providing jobs for unemployed youth, earning foreign currencies and improving socio-economic condition of Bangladesh. The sector contributes $3.65 \%$ to the national GDP and $23.81 \%$ to the total agricultural GDP. Fish and fishery products are the country's second largest export commodity contributing 1.97 percent of its exchange earnings in 2015-2016.

The fisheries resources of the country are broadly divided into three groups, i.e., inland capture, inland culture and marine capture of which the inland aquaculture has been contributing $>50 \%$ of the total production. ${ }^{3}$ The inland capture fishery comprised with five categories of habitats such as rive and estuary (853,863 ha), Sundarbans mangrove rainforests $(1,77,000$ ha), beels $(1,14,161$ ha), Kaptai Lake (68,800 ha) and floodplains (2,695,529 ha); and the inland culture fishery containing six types of habitats, viz., pond $(3,71,309 \mathrm{ha})$, seasonal cultured water body $(1,30,488)$, baor $(5,488$ ha), shrimp/prawn farm (2,75,274 ha), pen culture (6.78 ha), and cage culture (7 ha). ${ }^{4}$ A systematic time series data analysis for the study years 2003-2014 shows the decreasing trends of capture fishery to be 0.16 million, while the culture fishery habitat is increased by 0.35 million ha. ${ }^{1}$ Considering the inland culture fisheries and close water aquaculture, Bangladesh is now attained the fourth and fifth position in the world, respectively.

The total production of fish in Bangladesh was reported to be 3,684,245 mt during 2014-2015 in which 1,023,991 mt (27.79\%) were obtained from inland open waters, 2,060,408 mt (55.93\%) from 
closed waters and 599,846 $\mathrm{mt}$ (16.28\%) from marine fisheries (Table 1). The yearly increasing rate of overall fish production in Bangladesh decreased from $7.20 \%$ to $3.84 \%$ during the years $2000-2001$ to 2014 2015 , which included a decreasing yearly increase since a peak in $2009-2010$ at $7.32 \%$.

In Bangladesh, twelve fisheries laws have been identified towards execution for the regulation and management of the fisheries resources wherein a few have been implemented for regulating and managing of fisheries as well as protecting fish species. There are some limitations for the proper implementation of laws such as, lack of clear policy guidelines and strategy; inadequacy of existing regulatory framework; non-enforcement of legislation and jurisdictional conflicts; the absence of regular law review and updating mechanism and formulation of by-laws, rules, orders and so on. ${ }^{5}$ However, the practice of capture fisheries management includes recovering their stock and progressing along with implementing fisheries management regulations. The proper use of laws and regulations deemed very important for the possibility of proper exploitation and conservation of the capture fisheries resources. ${ }^{6}$

The capture fisheries policy in Bangladesh encompasses by the policy making process for utilizing the water body management as well as leasing government water bodies and earn revenue but these are not provided with secured access of the fisher communities and management due to the limited opportunities caused by the intervention of political leaders. So, it is a key hindrance to implement policy and also a variety of socio-economic factors that affect the governance in its need-based, proper and timely implementations. ${ }^{7}$

Table I Inland and marine fisheries production of Bangladesh., ${ }^{1,3}$

\begin{tabular}{llll}
\hline Types of fisheries & Sectors of fisheries & Water area (ha) & Production \\
\hline & Inland open water (capture): & $3,906,434$ & I,023,99| \\
& River, estuary, beel, lake and floodplain etc. & & \\
Inland fisheries & Inland closed water (culture): & 794,361 & $2,060,408$ \\
& Pond, seasonal water body, baor, prawn/shrimp farm, pen & \\
culture, cage culture, etc. & $4,700,795$ & $3,084,399$ \\
& Total & $12,111,000$ & 84,846 \\
Marine fisheries & Industrial (trawl) fishing: & & 515,000 \\
& Artisanal fishing & & 599,846 \\
Total production & Total & & $3,684,245$
\end{tabular}

\section{Capture fisheries legislation, regulations and policies}

The marine capture fishery comprises of two distinctive subsections such as large scale commercial (usually named as industrial fisheries in Bangladesh), artisanal and subsistence fisheries. ${ }^{5}$ According to the Article 143(3) of the constitution, Bangladesh passed laws both in Territorial Water and Maritime Zones Acts on $14^{\text {th }}$ of February in 1974 and also law of the sea in Bay of Bangal (BoB) was approved in 1982 Convention on the Law of the Sea (UNCLOS-III) in 2001. ${ }^{5}$

The government of Bangladesh makes laws, rules, policies, guidelines, ordinances and circulars time to time (Table 2) and regulates the capture water fisheries and it has been implemented based on the allocation of fishing right through periodic leasing. The inland capture fisheries such as rivers and beels are leased out on the basis of three years and in case of group fisheries, for 6 years and in some circustances, up to 9 years. ${ }^{8}$ The Ministry of Fisheries and Livestock (MoFL) states that the management of inland captures fisheries should be treated through the income of sub-district and the revenue might be distributed on the basis of their area and population.

The National Fisheries Policy in Bangladesh included various sectors such as government and autonomous organizations, multinational institutions, various nongovernmental organizations, voluntary organizations, persons etc. This policy also included all the water bodies for fisheries production, and their fisheries resources and conservation, development and management. Moreover, for the actual implementation of this policy, emphasis should need to be given to the four main sub-sectors namely Inland closed water bodies, Inland open waters, Coastal shrimp and fish culture, and Marine fisheries resources conservation and management. ${ }^{9}$ However, the NEMP (National Environmental Management Plan) identified several problems such as overfishing and exploitation of limited resources by the fishermen and middlemen, although their impact and success are less clear and also indiscretions and misuses in leasing fishing rights are widely reported, thus circumventing the intent of the policy. ${ }^{10}$

The MCS (Monitoring, Control and Surveillance) needed to apply for the management priorities in Bangladesh such as fisheries unveil a number of different fishery management situations, ranged from the local, specific stock and specific fishery of perhaps a few tones to a number of different trawl fisheries, and then a largely underexploited offshore fishery. ${ }^{11}$ It has also been recognized that reducing fish stocks to biologically and ecologically harmful levels will result in loss of potential benefits as food, income, employment and others, both immediate and in long-term..$^{12}$ The greatest impacts on fisheries stem from the domestic fishing industry in the coastal and near-shore fishing zones are needed to be addressed and controlled. Therefore, the statement of fisheries act (in 1983), which provided fishing control on the basis of operations, is now in the particular problem of illegal fishing conducted by domestic and foreign vessels. ${ }^{11}$

In Bangladesh under the Protection and Conservation of Fish Act1950, juvenile hilsa (jatka) (up to $23.0 \mathrm{~cm}$ size) catch, transportation, marketing, selling and possessing have been banned between 01 
November and 31 May in every year. In recent years, Bangladesh navy has implemented fishery protection campaigns on the basis of season (from January to March) to protect the most popular fish Hilsha (Tenualosa ilisha). This campaigns usually called "operation Jhatka". ${ }^{13}$ Bangladesh enforced a 22-day ban on Hilsa fishing in 27 districts in a view to increase the inhabitants of the popular fish species, which contributes more than one $1 \%$ of the country's gross domestic product (GDP). Catching, selling, transportation, storage and exchange of Hilsa fish is now banned across the country and will be particularly enforced in a 7,000 square $\mathrm{km}$ area designated as breeding zone. The government has deployed the coast guard, naval police and other forces to ensure whether fishermen are obeying the ban. The Economics Times compelled that if anyone is found breaking the ban could face a fine between 5,000 to 10,000 Taka (US\$ 63 to US\$ 127), confiscating of fishing equipment and up to two years in prison, said by Chandpur Fisheries official Mohammed Safiqur Rahman. ${ }^{14}$

Table 2 Related fishery policies, laws, rules, acts and ordinances in Bangladesh. ${ }^{5}$

Fisheries Laws in Bangladesh

The Private Fisheries Protection Act, 1889

The Protection and Conservation of Fish Act, 1950

The Protection and Conservation Fish Rules, 1985

The Fish and Fish Product (Inspection and quality control) Ordinance, 1983

The Fish and Fish Products (Inspection \& Quality Control) Rules, 1997

Marine Fisheries Ordinance, 1983

Marine Fisheries Rules, 1983

Pond Development Act, 1939

National Fisheries Policy, 1998

National Shrimp Policy, 20I4

Territorial Water and Maritime Zone Act, 1974

Territorial Water and Maritime Zone Rules, 1977

\section{Governance systems}

Fisheries in Bangladesh is playing an important role as well as contributing a lot in the diverse sectors for meeting nutritional requirements, generating employment and earning foreign exchange by providing about $60 \%$ of the requirement for animal protein intake. ${ }^{15}$ Most of the peoples have been involved directly or indirectly in fisheries, which refer to as the direct employments of around 1.32 million people as well as an estimated 14.7 million people earn their livelihood from indirect employment. ${ }^{16}$ The Government are taking prime responsibility to manage these sectors by its representatives, principally the Department of fisheries. These sectors are managed and controlled by large activity where it has directly involved in some of the input allocation such as fingerling supply. However, several organizations and institutions are involved in development and management of fisheries in Bangladesh where MoFL is the main and lead administrative agency, responsible for drafting, formatting and implementing the fisheries rules and regulations (Figure 1).

In Bangladesh, Ministry of Fisheries and Livestock (MoFL) under the GoB (Government of Bangladesh) is leading different institutions such as Department of Fisheries (DoF), which has largely been involved in activities related to extension, management, project implementation, training and human resource development, enforcement of laws and regulations, conservation, quality control, registration and certification, fishing licenses, fisheries awareness building and motivation, support to policy formulation, and administration. ${ }^{18}$ Secondly, Bangladesh Fisheries Development Corporation (BFDC) has been taking action on marketing, production, training etc. Moreover, Bangladesh Fisheries Research Institute (BFRI) is taking action on fisheries and other aquatic animal related research and training. Finally, Fisheries and Livestock Information Department (FLID) has been taking action on dissemination of fisheries and livestock related information. ${ }^{15}$

However, Government and donor aid has supported several projects on the basis of community-based management for inland capture fisheries over the last two decades, which has successfully been initiated by DoF and also shows the outstanding performance under the Consultative Group on International Agricultural Research (CGIAR) that also awarded CGIAR Science Award-2004 to Community Based Fisheries Management Project. ${ }^{19}$

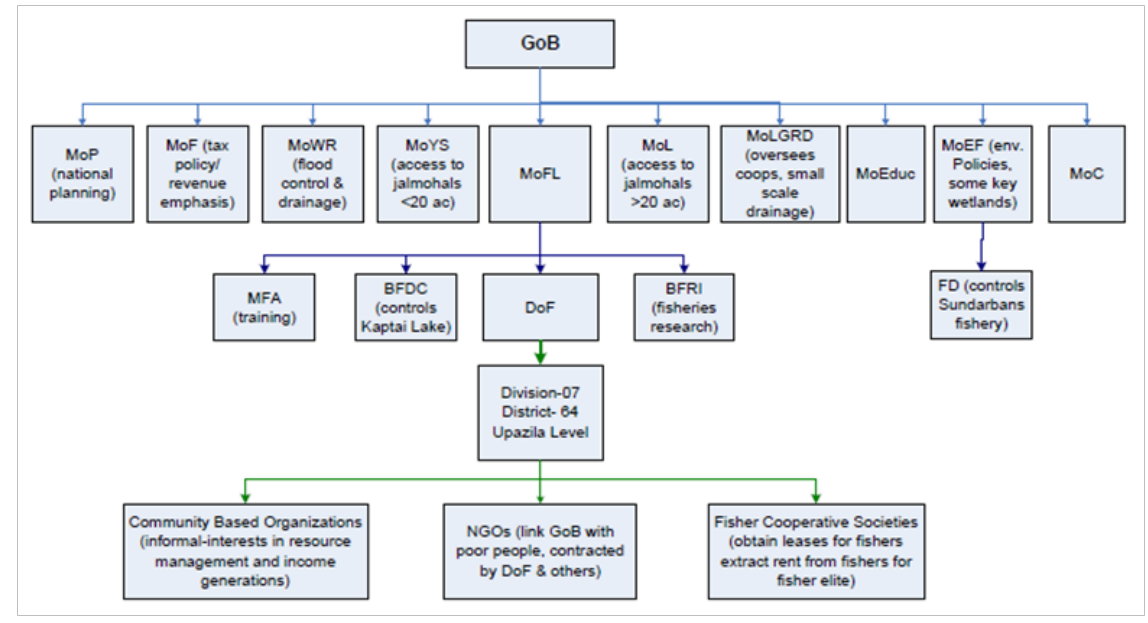

Figure I Roles of government and non-government organizations in fisheries of Bangladesh.,17 


\section{Management strategies}

In Bangladesh, fisheries are attributed by the nature of the water bodies through the climate change. The impact of climate change, owing to their potentially vast reach and scale, embody a critical challenge such as loss of habitat, change in habitat condition, disease outbreak, obstacles in migration routes and reproduction, and reduced fisheries production..$^{20,21}$ In the contemplation of climate change, Bangladesh government have taken initiative for an adaptive management based fisheries strategy. In this purpose, they have recently established a National Climate Change Fund, with an initial capital of 45 million USD and later raised to 100 million USD, which have focused mainly on adaptation to climate change effects. They included fisheries as the first pillar of the Bangladesh Climate Change Strategy and Action Plan. ${ }^{21}$ In the capture fisheries, they have applied appropriate adaptation techniques for maintaining a steady yield and a living standard for the fishing-dependent communities. They also have selected fisheries management techniques for capture fisheries based on suitable adaptive measures, awareness on the techniques used and developing implementation skill and responsibility to everyone. Pointedly, they considered the stability of adaptation in capture water bodies towards its sustainable management. These adaptation techniques have been used in the following areas such as, development and restoration of aquatic habitat and biodiversity conservation, ${ }^{22}$ enhancing fisheries stock, ${ }^{23}$ development and expansion of community based water body management in rivers, beels, floodplains, baors and lagoons, development and re-excavation of the connecting drainage channels where required for unimpeded water flow, increasing the depth of water bodies, and ensuring undisturbed and unimpeded migration of fishes. ${ }^{15}$

\section{Management measures in the case study of hilsa fishery}

In Bangladesh, most of the peoples are directly dependent on fish but nowadays fish are gradually decreasing due to the impact for abuse of resources. For this reason, Bangladesh Government has taken lots of initiative to save the main asset of this country. Hisha is a national fish of Bangladesh but its demands have gradually been decreased because of the early or blunder catch. However, the Bangladesh fisheries authority has taken several measures for conservation and management of the artisanal hilsa fishery in Bangladesh. ${ }^{24}$

In case of gear restriction, the basic act regulating inland fisheries is the Protection and Conservation of Fish Act (1950), as amended by the Protection and Conservation of Fish Amendment Ordinance (1982) and implemented by the Protection and Conservation of Fish Rules (1985). There are several protection and conservation measures for hilsa based on these two acts and other legislation. They include closing some areas to fishing, restrictions on fishing gear, restrictions on the fishing season and regulations for fishing vessels. Conferring to this act, jatka (small Tenualosa ilisha) fish catch has been banned in Bangladesh between and June each year ${ }^{25}$ and most jatka caught are illegal. Mostly, the poor fishers catch fish illegally by using ban net as they lack of suitable alternative livelihood activity during the period of jatka fishing. This restriction implements to protect jatka which are caught illegally by fishers in large quantities with gillnets and seine nets of various mesh size during the scraping period of river and shore. ${ }^{26}$ The different uses of current jal (monofilament gillnet) under the size of $4.5 \mathrm{~cm}$ mesh size has been banned from the period of 1988. In small scale inland capture T. ilisha fisheries, the operation or mechanism of gill nets of less than $100 \mathrm{~mm}$ mesh size is legally prohibited for the conservation or protection purposes. ${ }^{27}$ However, the effective enforcement measures in critical sites and in the breeding period could significantly contribute to the production as well as maintenance of its biodiversity to a greater extent. In recent years, Bangladesh Government has taken strong initiatives towards the conservation and management of hilsa stocks, both to optimize total production and ensure fisher's livelihoods. ${ }^{28}$

\section{Conclusion}

In conclusion, the Bangladesh fisheries have ample scope of development to strengthen the national economy and therefore, the Government of Bangladesh (GoB) in its vision 2021, set a target to reach the goals and self-sufficiency in food and thus have given emphasis to increase the food security that includes a clear long-term policy towards attaining the self-sufficiency in fish production. In the formulation of fisheries policy, inter-government departmental coordination, collaboration between governmental and nongovernmental organizations (GO-NGOS) and the simulation of public response are of prime importance. In order to understand the potential, there is a strong need to adjust the prevailing laws and legislation for the sustainable management and conservation of fisheries resources in the country. The fishers, fish farmers, suppliers, processors, traders and consumers as a whole are needed to realize these matters to be involved in the management plans for getting benefit from the entire process. The management measures should include regulating fishing intensity at a sustainable level, control gear selectivity, gear type and size of fish, implementation of closed season, prohibition of destructive fishing, closed fish sanctuary, and allocation of fisheries resources such as manpower, finance, subsidy etc. Following the fisheries policy, the Bangladesh Government must legislate a comprehensive legal framework for the proper management and utilization of its resources in the purposes of the sustainable development of the country and welfare of its peoples. Concerned government institutions, development partners, professionals, researchers and non-government organizations can play important roles towards the advancement of fisheries sector in commensurate with the national and international demands.

\section{Acknowledgments}

None.

\section{Conflicts of interest}

The authors declare there is no conflict of interest.

\section{References}

1. Shamsuzzaman MM. Towards sustainable development of coastal fisheries resources in Bangladesh: An analysis of the legal and institutional framework. Turkish Journal of Fisheries and Aquatic Sciences. 2017;17(4):833-4841.

2. DoF. National fish week, compendium (in Bengali). Department of Fisheries (DoF), Ministry of Fisheries and Livestock. Dhaka, Bangladesh: Government of Bangladesh; 2017.

3. DoF. National fish week, compendium (in Bengali). Department of Fisheries (DoF), Ministry of Fisheries and Livestock. Dhaka, Bangladesh: Government of Bangladesh; 2016.

4. FRSS. Fisheries Statistical Report of Bangladesh. Fisheries Resources Survey System (FRSS), Department of Fisheries, 2016;32:1e57.

5. Shamsuzzaman MM, Xiangmin X, Islam MM. Legal status of Bangladesh fisheries: issues and responses. Indian Journal of Geo Marine Sciences. 2016;45(11):1474-1480. 
6. Natheer A, Teruhisa K. Characterization of fisheries management in Yemen: A case study of a developing country's management regime. Marine Policy. 2014;50(A):89-95.

7. Firoz KAKM, Mustafa, MG, Niamul N. Effective supervision of inland capture fisheries of Bangladesh and its hurdles in managing the resources. Journal of Global South. 2016;3:17.

8. MoL. Ministry of Land memorandum Number Bhum/7/5/91/424 (12), Section 2, 1991.

9. Serajul Islam, Hasneen Jahan, Abdullah Al-Amin. Fisheries and aquaculture sectors in Bangladesh: an overview of the present status, challenges and future potential. Journal of Fisheries and Aquaculture Research. 2016;1(1):002-009.

10. MoL. Ministry of Land, Memorandum No. BHU.Mo.Bya1/87/13 (64), 2015.

11. BOBP-IGO. National Workshop on Monitoring, Control and Surveillance in Marine Fisheries - Bangladesh. 2009. 104 p.

12. Yugraj SY. Monitoring, control and surveillance in small-scale fisheries - guiding principles and practices. GoB/DANIDA/BOBP-IGO National Workshop on Monitoring, Control and Surveillance in Marine Fisheries - Bangladesh, Cox's Bazaar, Bangladesh. 2008.

13. DoF. National fish week, compendium (in Bengali). Department of Fisheries (DoF), Ministry of Fisheries and Livestock. Dhaka, Bangladesh: Government of Bangladesh; 2006.

14. The Economic Times. Bangladesh imposes 22-day ban on Hilsa fishing. 2018 .

15. BanDuDeltAS. Fisheries. Bangladesh Delta Plan 2100 Formulation Project. General Economics Division, Planning Commission, Government of Bangladesh, 2015.

16. Hossain MAR, Kabir H, Faruque AMO, et al. Livelihood security: Implications from aquaculture sectors. In: Habiba, editor. Food Security and Risk Reduction in Bangladesh. Japan: Springer; 2015:83-109.

17. Ali ML, Alam SS, Ahmed SA. Bangladesh Country Status Report. Understanding livelihoods dependent on inland fisheries in Bangladesh and Southeast Asia (DFID/FMSP Project R8118), BCAS, Dhaka. 2003. 57 p.
18. Shamsuzzaman MM, Islam MM, Tania NJ, et al. Fisheries resources of Bangladesh: Present status and future direction. Aquaculture and Fisheries. 2017;2(4):145-156.

19. Dickson M, Brooks A. CBFM-International Conference on Community Based Approaches to Fisheries Management. The WorldFish Center Conference Proceedings. 2007;75:38.

20. John E Thornes. IPCC, Climate Change 2001: Impacts, Adaptation, and Vulnerability. Contribution of Working Group II to the Third Assessment Report of the Intergovernmental Panel on Climate Change (IPCC). Cambridge, UK: Cambridge University Press. 2001. 1032 p.

21. MoEF. Bangladesh Climate Change Strategy and Action Plan (BCCSAP'09). Ministry of Environment and Forests (MoEF) with technical support from IUCN Bangladesh Country Office. 2009.

22. Mustafa MG, Sharmin SE. Climate change implications for fisheries and aquaculture in Bangladesh: A review. Institute of Water and Flood Management (IWFM), Bangladesh University of Engineering and Technology (BUET); 2010.

23. Magawata I, Ipinjolu JK. Climate change: Mitigation and adaptation strategies in fisheries and aquacultures in Nigeria. Journal of Fisheries and Aquatic Science. 2014;9(4):257-262.

24. Food and Agriculture Organization of the United Nations. Small-scale and artisanal fisheries. Rome: FAO; 2014.

25. Haldar GC, Islam, MR. Akanda MSI. Implementation strategies of hilsa fisheries conservation and development management (in Bengali). 4th Fisheries Project. Department of Fisheries, Ministry of Fisheries and Livestock, Dhaka, Bangladesh: Government of Bangladesh; 2004.

26. Siddique MAL. Conservation of juvenile hilsa (jatka) in Bangladesh: Need to address the livelihood of fishers. American Fisheries Society Symposium. 2009;69:757-768.

27. Monirul I, Essam YM, Liaquat A. Economic incentives for sustainable hilsa fishing in Bangladesh: An analysis of the legal and institutional framework. Marine Policy, 2016;68:8-22.

28. Mohammed EY, Wahab MA. Direct economic incentives for sustainable fisheries management: The case of hilsa conservation in Bangladesh. London: International Institute for Environment and Development (IIED); 2013. 